\title{
ANALISIS PENGARUH FAKTOR-FAKTOR FUNDAMENTAL TERHADAP HARGA SAHAM PADA PERUSAHAAN MANUFAKTUR DI BURSA EFEK INDONESIA (BEI)
}

\author{
Dermawan Wijaya \\ Program Studi Magister Manajemen Universitas Tarumanagara \\ dermawanwijaya@gmail.com
}

Masuk : 27-11-2017, revisi : 15-12-2017 diterima untuk diterbitkan : 15-12-2017

\begin{abstract}
This research aims to analyze the effect of fundamental factors on stock price in manufacturing companies which are listed in the Indonesia Stock Exchange. Fundamental factors that become this research objects are current ratio (CR), debt to equity (DER), return to equity ratio (ROE), total assets turnover (TATO) and earning per share (EPS) as independent variables, while stock price becomes dependent variables. The research subjects are manufacturing companies listed in Indonesia stock Exchange between period of 2013-2016 and have published profitable financial statements. Sampling method used is purposive sampling and the analysis method used is panel data regression. The research model selected is fixed effect model (FEM). The result shows that CR, DER, ROE, TATO and EPS has significant and simultaneous effects on stock price. Where only ROE and EPS has significant and partial effect on stock price. This study concludes that not all independent variables have significant effect on stock price.
\end{abstract}

Keywords: Current Ratio, Debt to Equity Ratio, Return to Equity Ratio, Total Asset Turnover, Earning Per Share

\section{PENDAHULUAN}

Secara umum pasar modal adalah sarana tempat bertemunya permintaan dan penawaran instrumen keuangan jangka panjang, umumnya lebih dari 1 (satu) tahun. Pasar modal merupakan salah satu elemen sistem ekonomi yang turut memacu pertumbuhan dan perkembangan ekonomi dan bisnis. Instrumen keuangan jangka panjang yang bisa digunakan investor sebagai pilihan berinvestasi diantaranya yaitu saham, obligasi, reksadana, instrumen derivatif (opsi dan futures).

Bursa Efek Indonesia (BEI) atau Indonesia Stock Exchange (IDX) merupakan pasar modal yang ada di Indonesia. BEI memegang peranan penting sebagai sarana bagi masyarakat untuk berinvestasi, yang juga merupakan salah satu alternatif untuk menanamkan modal. Diantara instrumen pasar modal diatas yang paling populer adalah saham (Samsul, 2006).

Investasi dalam bentuk saham mempunyai risiko yang sesuai dengan prinsip investasi yaitu high risk high return. Semakin tinggi potensi keuntungan semakin tinggi pula kemungkinan risiko yang akan dialami oleh investor, demikian sebaliknya. Potensi keuntungan dari investasi dalam bentuk saham relatif lebih besar dari pada investasi dalam bentuk financial assets lainnya seperti instrumen pasar uang, obligasi, dan reksadana.

Menurut Setiyawan dan Pardiman (2014) salah satu hal yang harus menjadi fokus pertimbangan seorang investor adalah harga saham. Harga saham yang diharapkan oleh investor adalah harga saham yang stabil dan mempunyai pola pergerakan yang cenderung naik dari waktu ke waktu, akan tetapi kenyataannya harga saham cenderung berfluktuasi. Karena harga suatu saham ditentukan menurut hukum permintaan dan penawaran, semakin banyak investor yang membeli saham, maka harga saham tersebut menaik dan sebaliknya jika banyak investor yang menjual sahamnya maka harga saham tersebut cendurung menurun. Maka tidak ada harga saham yang akan terus menerus bergerak naik demikian pula tidak ada harga saham yang akan terus menerus bergerak turun. Sebab itu investor perlu melakukan analisis sekuritas 
untuk menentukan saham perusahaan mana yang akan dibeli dan kapan harus melakukan transaksi jual beli saham.

Bursa Efek Indonesia menerbitkan laporan keuangan perusahaan yang terdaftar setiap tahun dan setiap tiga bulan. Informasi yang terdapat dalam laporan keuangan cukup penting dan bermanfaat karena dapat memberikan gambaran tentang kinerja perusahaan. Informasi tersebut dapat digunakan sebagai landasan untuk mengambil keputusan investasi.

\section{Pokok Masalah}

1. Apakah Current Ratio (CR) berpengaruh terhadap harga saham?

2. Apakah Debt to Equity Ratio (DER) berpengaruh terhadap harga saham?

3. Apakah Return on Equity Ratio (ROE) berpengaruh terhadap harga saham?

4. Apakah Total Asset Turnover (TATO) berpengaruh terhadap harga saham?

5. Apakah Earning per Share (EPS) berpengaruh terhadap harga saham?

6. Apakah CR, DER, TATO, ROE dan EPS berpengaruh secara bersama-sama terhadap harga saham?

\section{Tujuan Penelitian}

1. Untuk mengetahui pengaruh Current Ratio (CR) terhadap harga saham.

2. Untuk mengetahui pengaruh Debt to Equity Ratio (DER) erhadap harga saham.

3. Untuk mengetahui pengaruh Return on Equity Ratio (ROE) terhadap harga saham.

4. Untuk mengetahui pengaruh Total Asset Turnover (TATO) terhadap harga saham.

5. Untuk mengetahui pengaruh Earning per Share (EPS) terhadap harga saham.

6. Untuk mengetahui pengaruh CR, DER, TATO, ROE dan EPS secara bersama-sama terhadap harga saham.

\section{TELAAH KEPUSTAKAAN}

Menurut Alwi (2003) saham atau stock adalah surat tanda bukti atau tanda kepemilikan terhadap suatu perusahaan suatu perseroan terbatas. Sedangkan menurut Husnan (2001) saham merupakan surat bukti pemilik yang menginformasikan bagian modal atau tanda penyertaan modal pada perseroan terbatas yang memberikan hak atas dividen dan lain-lain menurut besar kecil modal pada saat disetor. Porsi kepemilikan ditentukan oleh seberapa besar penyertaan modal yang ditanamkan di perusahaan tersebut (Darmadji \& Fakhruddin, 2012).

Nurdhiana (2011) menyatakan bahwa harga saham dapat didefinisikan sebagai harga pasar. Sedangkan Darmadji dan Fakhruddin (2012:102) harga saham dapat berubah menjadi naik ataupun turun dalam tempo cepat karena hal tersebut tergantung dari permintaan dan penawaran yang terjadi antara pembeli dan penjual saham.

\section{Faktor-faktor yang Mempengaruhi Harga Saham}

Arkan (2016) menyebutkan faktor-faktor yang mempengaruhi harga saham "These factors could bepresented as: Book Value of Stock, Profit Realize per share, Dividends at the end of year, Future of Facility and The Strenght of Financial Position, General Economic Condition, Rumours in Financial Market, Supply and Demands Situation on Stock, Interest Rate".

Menurut Irham (2012:2) kinerja keuangan adalah suatu analisis yang dilakukan untuk melihat sejauh mana suatu perusahaan telah melaksanakan dengan menggunakan aturan-aturan pelaksanaan keuangan secara baik dan benar. Kinerja perusahaan merupakan suatu gambaran tentang kondisi keuangan suatu perusahaan yang dianalisis dengan alat-alat analisis keuangan, sehingga dapat diketahui mengenai baik buruknya keadaan keuangan suatu perusahaan yang mencerminkan prestasi kerja dalam periode tertentu. Hal ini sangat penting agar sumber daya digunakan secara optimal dalam menghadapi perubahan lingkungan.

Untuk mengetahui apakah kondisi dan kinerja keuangan perusahaan dalam kondisi baik atau tidak, yaitu dengan melakukan analisa laporan keuangan. Salah satu cara menganalisa laporan keuangan yaitu dengan melakukan analisa rasio keuangan. 
Rasio keuangan merupakan kegiatan membandingkan angka-angka yang ada dalam laporan keuangan dengan cara membagi satu angka dengan angka lainnya (Kasmir, 2014). Menurut Arkan (2016), membagi rasio keuangan dalam 5 jenis berdasarkan ruang lingkup atau tujuan yang ingin dicapai. Kelima rasio tersebut adalah:

1. Liquidty (solvency) Financial Ratio

Rasio ini terdiri dari: current ratio dan quick ratio. Rasio likuiditas dalam penelitian ini diwakili oleh current ratio. Menurut Arkan (2016) menyatakan current ratio "Shows the company's ability to meet its current obligation (or pay off debt)", dengan rumus:

$$
\text { Current Ratio }(\mathrm{CR})=\frac{\text { Current Assets }}{\text { Current Liabilites }}
$$

\section{Leverage (debit) Financial Ratio}

Rasio leverage yang paling umum adalah debt ratio, debt to equity ratio, long term debt ratio, time interest earned ratio, fixed charge coverage ratio and cash coverage ratio. Rasio leverage dalam penelitian ini diwakili oleh debt to equity ratio. Menurut Arkan (2016) menyatakan debt to equity ratio (DER) "Direct comparison of debt to equity stakeholders and the most common measure of capital structure", dengan rumus: Debt to Equity Ratio $(D E R)=$

$$
\frac{\text { Total Liabilities }}{\text { Total Stockholders Equity }}
$$

\section{Financial Operation Ratios (Asset Effeciency Ratios)}

Rasio ini terdiri dari fixed assset turnover ratio dan total assets turnover (TATO). Rasio keuangan dalam penelitian ini diwakili oleh total assets turnover. Menurut = Lako (2006: 190-192), total assets turnover ratio digunakan untuk mengukur seberapa efisien penggunaan seluruh aktiva perusahaan untuk menunjang kegiatan perusahaan, dengan rumus (Arkan, 2016):

$$
\text { Total Assets Turnover }(\text { TATO })=\frac{\text { Net Sales }}{\text { Total Assets }}
$$

\section{Profitability Financial Ratios}

Rasio ini terdiri dari return on total assets ratio, return on equity ratio, gross margin ratio, dan net profit ratio. Rasio profitabilitas dalam penelitian ini diwakili oleh return on equity ratio, dengan rumus (Arkan, 2016):

$$
\text { Return on Equity Ratio }(\text { ROE })=\frac{\text { Net Income }}{\text { Total Stockholders Equity }}
$$

\section{Valuation Ratios (Market Value Ratios)}

Kelompok rasio penilaian menunjukkan pada nilai pasar dari saham, dalam beberapa hal mengukur fundamental perusahaan seperti EP, book value, EPS, dan dividen. Rasio valuasi dalam penelitian ini diwakili oleh earning per share ratio. EPS menunjukkan perbandingan antara laba bersih dengan jumlah saham yang beredar, dengan rumus (Arkan ,2016):

$$
\text { Earning per Share }(E P S)=\quad \frac{\text { Earning after Tax }}{\text { Total Common Stock Outstanding }}
$$

\section{Kerangka Pemikiran}

Kerangka pemikiran terdiri dari skema kerangka pemikiran. Berikut adalah skema kerangka pemikiran dari penelitian ini: 


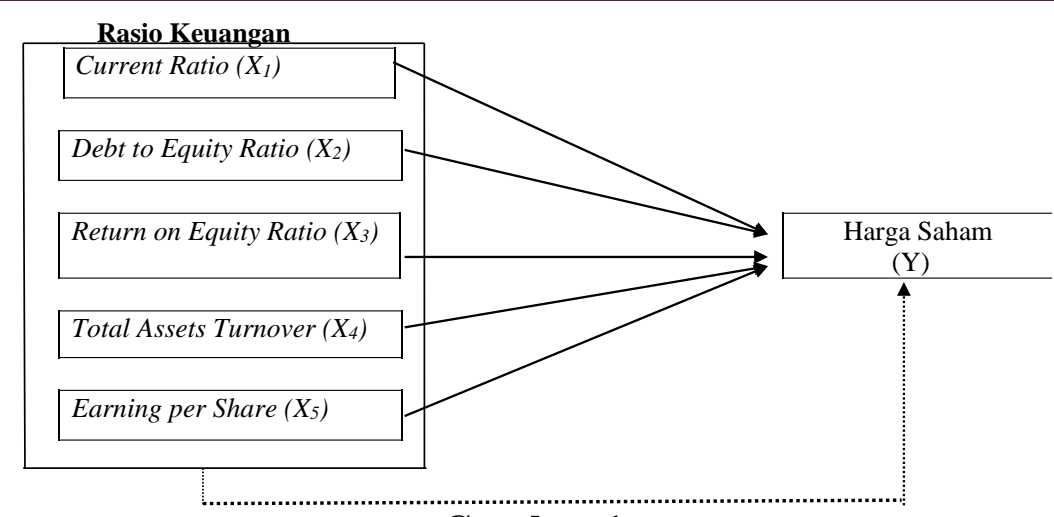

Gambar 1

Kerangka Pemikiran

Obyek penelitian terdiri atas variabel-variabel yang diteliti, yaitu:

a. Variabel Current Ratio $\left(\mathrm{X}_{1}\right)$ merupakan variabel bebas (independent variable)

b. Variabel Debt to Equity Ratio $\left(\mathrm{X}_{2}\right)$ merupakan variabel bebas (independent variable)

c. Variabel Return on Equity Ratio $\left(\mathrm{X}_{3}\right)$ merupakan variabel bebas (independent variable)

d. Variabel Total Assets Turnover $\left(\mathrm{X}_{4}\right)$ merupakan variabel bebas (independent variable)

e. Variabel Earning per Share $\left(\mathrm{X}_{5}\right)$ merupakan variabel bebas (independent variable)

f. Variabel harga saham (Y) merupakan variabel terikat (dependent variable)

\section{METODOLOGI PENELITAN}

Subjek penelitian adalah tempat di mana data untuk variabel penelitian diperoleh (Arikunto, 2010). Subjek yang diambil dalam penelitian ini adalah perusahaan manufaktur. Objek penelitian dalam penelitian ini sebagai variabel independennya adalah current ratio, debt to equity ratio, total assets turnover, return to equity ratio dan earning per share, sedangkan variabel dependennya adalah harga saham.

Sampel adalah bagian dari populasi yang menjadi objek penelitian yang dapat dianggap mewakili kondisi keadaan populasi. Sampel yang digunakan adalah perusahaan manufaktur yang terdaftar di BEI selama 4 tahun dengan jumlah 564 perusahaan dengan menggunakan metode purposive sampling. Metode ini digunakan dengan kriteria tertentu yang diharapkan memiliki informasi yang mewakili data yang akan diteliti, dalam hal ini kriteria sebagai berikut:

1. Perusahaan manufaktur yang terdaftar di Bursa Efek Indonesia periode 2013-2016

2. Perusahaan yang telah menerbitkan laporan keuangan tahunan yang berakhir pada tanggal 31 Desember mulai periode 2013 sampai dengan 2016 dan memperoleh laba atau keuntungan secara berturut-turut.

3. Harga saham perusahaan yang terakhir dalam transaksi jual beli di BEI pada saat penutupan akhir tahun.

\section{Metode Analisis}

\section{Teknik Regresi Data Panel}

Pemilihan model yang akan dipakai dalam penelitian diseleksi dengan uji spesifikasi model yang terdiri atas dua uji spesifikasi, yaitu efek tetap (fixed effects) atau efek random (random effect).

a. Uji Spesifikasi Model dengan Uji Chow

Uji Chow digunakan untuk memilih antara model fixed effect atau model common effect yang sebaiknya dipakai.

$\mathrm{H}_{0}$ : Common Effect Model

$\mathrm{H}_{\mathrm{a}}$ : Fixed Effect Model

Ketika model yang terpilih adalah fixed effect maka perlu dilakukan uji lagi, yaitu uji Hausman untuk mengetahui apakah sebaiknya memakai fixed effect model (FEM) atau random effect model (REM). 
b. Uji Spesifikasi Model dengan Uji Hausman

Uji Hausman digunakan untuk mengetahui model yang Hipotesis dalam uji Hausmann sebagai berikut:

$\mathrm{H}_{0}:$ Random Effect Model

$\mathrm{H}_{\mathrm{a}}$ : Fixed Effect Model

Jika $\mathrm{H}_{0}$ ditolak maka kesimpulannya sebaiknya memakai fixed effect model (FEM). Karena random effect model (REM) kemungkinan terkorelasi dengan satu atau lebih variabel bebas. Sebaliknya, apabila $\mathrm{H}_{\mathrm{a}}$ ditolak, maka model yang sebaiknya dipakai adalah random effect model (REM).

\section{Hipotesis}

Untuk membuktikan hipotesis diterima atau ditolak maka dalam penelitian ini dilakukan pengujian hipotesis, yaitu terdiri dari uji parsial (uji t) dan uji simultan (uji $F$ hitung dan $\mathrm{R}^{2}$ ).

a. Uji Parsial (uji t). Uji t digunakan untuk menguji koefisien regresi secara parsial dari variabel bebas terhadap variabel terikat.

b. Uji Simultan (uji F). Uji F ini merupakan pengujian terhadap signifikansi model secara simultan atau bersama-sama, yaitu melihat pengaruh dari seluruh variabel bebas terhadap variabel terikat.

c. Koefisien determinasi $\left(R^{2}\right)$. Pada intinya mengukur seberapa jauh kemampuan model dalam menerangkan variasi variabel dependen.

\section{HASIL ANALISIS DAN PEMBAHASAN \\ Uji Spesifikasi Model dengan Uji Chow}

Tabel 1

Hasil Uji Chow

\begin{tabular}{lrrr}
\hline \hline Effects Test & Statistic & d.f. & Prob. \\
\hline \hline Cross-section F & 1.147826 & $(71,211)$ & 0.2269 \\
Cross-section Chi-square & 94.058425 & 71 & 0.0349 \\
\hline \hline
\end{tabular}

Berdasarkan hasil tabel 1, terlihat bahwa nilai probabilitas dari Cross-section Chi-Square yakini sebesar 0.0349. Nilai tersebut kurang dari 0.05 hal ini berarti bahwa $\mathrm{H}_{0}$ ditolak dan $\mathrm{H}_{\mathrm{a}}$ diterima. Sehingga model yang dipilih adalah fixed effect model (FEM). Langkah selanjutnya maka perlu dilakukan uji lagi, yaitu uji Hausman untuk mengetahui apakah sebaiknya memakai fixed effect model (FEM) atau random effect model (REM).

Uji Spesifikasi Model dengan Uji Hausman

Tabel 2

Hasil Uji Hausman

\begin{tabular}{lrrr}
\hline \hline Test Summary & Chi-Sq. Statistic & Chi-Sq. d.f. & Prob. \\
\hline \hline Cross-section random & 13.038557 & 5 & 0.0230 \\
\hline \hline
\end{tabular}

Berdasarkan hasil tabel 2, terlihat bahwa nilai probabilitas Cross-section random yakini sebesar 0.0230. Nilai tersebut kurang dari 0.05 hal ini berarti bahwa $\mathrm{H}_{0}$ ditolak dan $\mathrm{H}_{\mathrm{a}}$ diterima. Sehingga model yang dipilih adalah fixed effect model (FEM). Maka selanjutnya melakukan regresi data panel sesuai model yang terpilih.

\section{Estimasi Regresi Data Panel Fixed Effect Model (FEM)}

Analisis regresi data panel dalam penelitian ini digunakan untuk mengetahui pengaruh CR, DER, ROE, TATO dan EPS terhadap harga saham, model yang dipilih fixed effect model (FEM). Berikut dibawah ini adalah tabel hasil estimasi regresi data panel dengan model fixed effect model (FEM):

Tabel 3

Hasil Analisis Regresi Panel FEM

\begin{tabular}{crrrr}
\hline \hline Variable & Coefficient & Std. Error & t-Statistic & Prob. \\
\hline \hline C & -61.73369 & 3129.893 & -0.019724 & 0.9843 \\
CR? & -463.0527 & 382.6961 & -1.209975 & 0.2276 \\
DER? & 165.9392 & 1030.443 & 0.161037 & 0.8722 \\
ROE? & -16511.95 & 7626.639 & -2.165036 & 0.0315
\end{tabular}




\begin{tabular}{ccccc}
\hline TATO? & 2053.762 & 1997.251 & 1.028294 & 0.3050 \\
EPS? & 22.30482 & 0.423650 & 52.64911 & 0.0000 \\
\hline \hline
\end{tabular}

Berdasarkan hasil analisis regresi panel tabel 3 menghasilkan nilai probabilitas untuk:

1. Variabel CR, DER dan TATO masing-masing sebesar 0.2276, 0.8722 dan 0.3050 lebih besar dari tingkat signifikan sebesar 0.05 atau $5 \%$ yang artinya variabel CR, DER dan TATO tidak signifikan sehingga tidak mempengaruhi harga saham pada perusahaan manufaktur di BEI pada periode 2013-2016.

2. Sedangkan variabel ROE dan EPS menghasilkan nilai probabilitas masing-masing sebesar 0.0315 dan 0.0000 lebih besar dari tingkat signifikan sebesar 0.05 atau $5 \%$ yang artinya variabel ROE dan EPS berpengaruh signifikan terhadap harga saham pada perusahaan manufaktur di BEI pada periode 2013-2016.

Dari hasil pengolahan data panel dengan menggunakan metode fixed effect model (FEM) dapat dibentuk model persamaan penelitian, seperti berikut ini:

$$
\mathrm{Y}_{\mathrm{it}}=\beta_{0}+\beta_{1} \mathrm{CR}_{\mathrm{it}}+\beta_{2} \mathrm{DER}_{\mathrm{it}}+\beta_{3} \mathrm{ROE}_{\mathrm{it}}+\beta_{4} \mathrm{TATO}_{\mathrm{it}}+\beta_{5} \mathrm{EPS}_{\mathrm{it}}+\varepsilon_{\mathrm{it}}
$$

Harga $_{i t}=-61.73369_{i t}-463.0527 \mathrm{CR}_{i t}+165.9392 \mathrm{DER}_{\mathrm{it}}-16511.95 \mathrm{ROE}_{\mathrm{it}}+2053.762 \mathrm{TATO}_{\mathrm{it}}+$

$$
\text { 22.30482EPS } \text { it }
$$

\section{Hipotesis}

Uji Parsial (uji t)

Pengujian ini dilakukan dengan membandingkan $p$ value $>0.05$ maka $\mathrm{H}_{0}$ diterima dan $\mathrm{H}_{\mathrm{a}}$ ditolak, yang artinya variabel independen yang diuji tidak berpengaruh secara signifikan terhadap variabel dependen. Sedangkan jika $p$ value $<0.05$ maka $\mathrm{H}_{0}$ ditolak dan $\mathrm{H}_{\mathrm{a}}$ diterima yang berarti variabel independen yang diuji berpengaruh secara signifikan terhadap variabel dependen.

Berdasarkan tabel 3, maka hasil output dapat disimpulkan sebagai berikut:

a. Variabel CR, DER, TATO memiliki $p$ value $>0.05$ maka $\mathrm{H}_{0}$ diterima dan $\mathrm{H}_{\mathrm{a}}$ ditolak. Sehingga CR, DER, TATO tidak berpengaruh signfikan terhadap harga saham.

b. Variabel ROE dan EPS memiliki $p$ value $<0.05$ maka $\mathrm{H}_{0}$ ditolak dan $\mathrm{H}_{\mathrm{a}}$ diterima. Sehingga ROE dan EPS berpengaruh signfikan terhadap harga saham.

\section{Uji Simultan (uji F)}

Jika nilai probabilitas $>0.05$, maka $\mathrm{H}_{\mathrm{o}}$ diterima dan $\mathrm{H}_{\mathrm{a}}$ ditolak, sehingga variabel independen dalam persamaan tidak berpengaruh terhadap variasi dari variabel dependen secara simultan. dan sebaliknya. Berikut dibawah ini adalah tabel dari hasil estimasi regresi data panel dengan model fixed effect model (FEM) yang menjabarkan nilai $F$-statistic dan Prob ( $F$ statistic):

\section{Tabel 4}

Hasil Uji F dan R-Squared FEM

\begin{tabular}{llll}
\hline R-squared & 0.985026 & F-statistic & 182.6297 \\
Adjusted R-squared & 0.979632 & Prob(F-statistic) & 0.000000 \\
\hline
\end{tabular}

Berdasarkan tabel 4, maka hasil output dapat disimpulkan bahwa nilai probabilitas $(F$ statistic) $0.0000<0.05$ berarti $\mathrm{H}_{\mathrm{o}}$ ditolak dan $\mathrm{H}_{\mathrm{a}}$ diterima, sehingga dapat disimpulkan bahwa seluruh variabel independen secara bersama-sama berpengaruh signifikan terhadap variabel dependen. Variabel CR, DER, ROE, TATO dan EPS secara bersama-sama berpengaruh signifikan terhadap harga saham pada perusahaan maufaktur di Indonesia yang terdaftar di BEI dari periode 2013-2016.

\section{Koefisien Determinasi $\left(\mathbf{R}^{2}\right)$}

Apabila $R^{2}$ yang mendekati 1 (satu) berarti variabel-variabel independen memberikan hampir semua informasi yang dibutuhkan untuk memprediksi variasi variabel dependen. Berdasarkan tabel 4.5., maka hasil output dapat disimpulkan bahwa $R$-squared $\left(\mathrm{R}^{2}\right)$ sebesar 0.985026 dan adjusted $R$-squared sebesar 0.979632 atau $97.96 \%$. Berarti dapat disimpulkan bahwa kemampuan variabel independen (CR, DER, ROE, TATO dan EPS) dalam menjelaskan 
variabel dependen (harga saham) sebesar $98.50 \%$ sisanya sebesar $1.50 \%$ dijelaskan oleh variabel lain diluar model.

\section{Pembahasan}

\section{Pengaruh Current Ratio (CR) terhadap Harga Saham}

Hasil pengujian hipotesis menyimpulkan bahwa $\mathrm{CR}$ berpengaruh negatif namun tidak berpengaruh signifikan terhadap harga saham pada perusahaan manufaktur di BEI pada periode 2013-2016. Current ratio bukanlah satu-satunya rasio yang berpengaruh pada perusahaan tersebut. Hasil penelitian ini sesuai dengan penelitian Palandeng (2012), Kusumadewi (2015) bahwa CR tidak berpengaruh signifikan terhadap harga saham. Sedangkan menurut Yusuf, Surahmat, dan Rahayu (2016) CR berpengaruh signifikan terhadap harga saham.

\section{Pengaruh Debt to Equity Ratio (DER) terhadap Harga Saham}

Hasil pengujian hipotesis menyimpulkan bahwa DER berpengaruh positif namun tidak berpengaruh signifikan terhadap harga saham pada perusahaan manufaktur di BEI pada periode 2013-2016. Dalam hasil penelitian ini menjelaskan bahwa tinggi atau rendahnya nilai DER tidak menunjukkan pengaruh naik atau turunnya harga saham. Hasil penelitian ini sesuai dengan penelitian Zulkarnaen, Muhammad dan Maulana (2016), Palandeng (2012), Darmawan (2014), Ponggohong, Murni, dan Mangantar (2016), Yusuf, Surahmat, dan Rahayu (2016) bahwa DER tidak berpengaruh signifikan terhadap harga saham.

\section{Pengaruh Return on Equity Ratio (ROE) terhadap Harga Saham}

Hasil pengujian hipotesis menyimpulkan bahwa ROE berpengaruh negatif dan berpengaruh signifikan terhadap harga saham pada perusahaan manufaktur di BEI pada periode 2013-2016. Apabila terjadi penurunan laba bersih maka nilai ROE pun akan turun begitupun sebaliknya dengan meningkatnya laba bersih maka nilai ROE akan meningkat pula jika ekuitasnya tetap dan berpengaruh terhadap pergerakan harga saham perusahaan manufaktur di BEI pada periode 2013-2016. Hasil penelitian ini sesuai dengan penelitian Qqribulloh (2013), Ponggohong, Murni, dan Mangantar (2016), Yusuf, Surahmat, dan Rahayu (2016) bahwa ROE berpengaruh signifikan terhadap harga saham. Sedangkan menurut Kusumadewi (2015) ROE tidak berpengaruh signifikan terhadap harga saham.

\section{Pengaruh Total Asset Turnover (TATO) terhadap Harga Saham}

Hasil pengujian hipotesis menyimpulkan bahwa TATO berpengaruh positif namun tidak berpengaruh signifikan terhadap harga saham pada perusahaan manufaktur di BEI pada periode 2013-2016. Dalam hasil penelitian ini menjelaskan bahwa besar atau kecilnya nilai TATO pada suatu perusahaan, tidak memberikan pengaruh naik atau turunnya harga saham untuk perusahaan. Hasil penelitian ini sesuai dengan penelitian Zulkarnaen, Muhammad dan Maulana (2016), Palandeng (2012), Ponggohong, Murni, dan Mangantar (2016), Yusuf, Surahmat, dan Rahayu (2016) bahwa TATO tidak berpengaruh signifikan terhadap harga saham.

\section{Pengaruh Earning Per Share (EPS) terhadap Harga Saham}

Hasil pengujian hipotesis menyimpulkan bahwa EPS berpengaruh positif namun berpengaruh signifikan terhadap harga saham pada perusahaan manufaktur di BEI pada periode 2013-2016. EPS yang semakin tinggi nilainya merupakan hal yang yang menggembirakan pemegang saham karena semakin besar laba yang disediakan untuk pemegang saham, maka investor akan tertarik untuk membeli saham perusahaan sehingga dapat meningkatkan harga saham. Hasil penelitian ini sesuai dengan penelitian Qqribulloh (2013), dan Aditya (2014) bahwa EPS berpengaruh terhadap harga saham. Sedangkan menurut Yusuf, Surahmat, dan Rahayu (2016) EPS tidak berpengaruh signifikan terhadap harga saham.

Variabel CR, DER, ROE, TATO dan EPS secara bersama-sama berpengaruh signifikan terhadap harga saham pada perusahaan manufaktur di Indonesia yang terdaftar di BEI dari periode tahun 2013-2016. Sedangkan kemampuan variabel independen dalam menjelaskan variabel dependen (harga saham) sebesar $98.50 \%$ sisanya sebesar $1.50 \%$ dijelaskan oleh variabel lain diluar model. 


\section{KESIMPULAN}

1. Variabel CR, DER. TATO tidak signifikan berpengaruh terhadap harga saham pada perusahaan manufaktur di BEI pada periode 2013-2016.

2. Variabel ROE dan EPS signifikan berpengaruh terhadap harga saham pada perusahaan manufaktur di BEI pada periode 2013-2016.

3. Variabel CR, DER, ROE, TATO dan EPS secara bersama-sama berpengaruh signifikan terhadap harga saham pada perusahaan maufaktur di Indonesia yang terdaftar di BEI dari periode tahun 2013-2016.

\section{DAFTAR PUSTAKA}

Alwi, I. Z. (2003). Pasar Modal Teori dan Aplikasi (Edisi Pertama). Jakarta: Penerbit Yayasan Pancur Siwah.

Ang, R. (2001). Buku Pintar Pasar Modal Indonesia. Jakarta: Mediassoft Indonesia.

Arikunto, S. (2010). Prosedur Penelitian Suatu Praktek. Jakarta: Rineka Cipta.

Arkan, T. (2016). The importance of financial ration in predicting stock price trends: A case study in emerging markets. Finanse, Rynki Finansowe, Ubezpieczenia Journal, 1(79).

Darmadji, T. \& Fakhruddin, H. M. (2012). Pasar Modal Indonesia (Edisi Ketiga). Jakarta: Salemba Empat.

Husnan, S. (2001). Dasar-Dasar Teori Portofolio dan Analisis Sekuritas. Yogyakarta: Penerbit AMP YKPN.

Irham, F. (2012). Analisis Laporan Keuangan. Bandung: Penerbit Alfabeta.

Kasmir. (2014). Analisis Laporan Keuangan (Edisi Satu, Cetakan Ketujuh). Jakarta: PT. Raja Grafindo Persada.

Kusumadewi, A. (2015). Pengaruh likuiditas dan profitabilitas terhadap harga saham perusahaan manufaktur yang terdaftar di Bursa Efek Indonesia periode 2010-2013. Jurnal Akuntansi. UNDINUS.

Lako, A. (2006). Relevansi Informasi Akuntansi untuk Pasar Saham Indonesia: Teori dan Bukti Empiris. Yogyakarta: Penerbit Amara Books.

Nurdhiana, F. H. M. (2011). Pengaruh book value, price to book value, earning per share (EPS), dan price earning ratio (PER) terhadap harga saham perusahaan food and beverage yang terdaftar di Bursa Efek Indonesia tahun 2007-2010. Jurnal Akuntansi. STIE Widya Manggala.

Palandeng, F. P. C. (2012). Analisis faktor-faktor fundamental terhadap harga saham perusahaan farmasi yang go public di Bursa Efek Indonesia. Tesis. Universitas Tarumanagara. Jakarta.

Ponggohong, J. O.Y., Murni, S. \& Mangantar, M. (2016). Pengaruh kinerja keuangan terhadap harga saham (Studi pada perusahaan ritel yang terdaftar di BEI tahun 2010-2013). Jurnal Berkalah Ilmiah Efisiensi, 16(1).

Samsul, M. (2006). Pasar Modal dan Manajemen Portofolio. Jakarta: Penerbit Erlangga.

Setiyawan, I. \& Pardiman. (2014). Pengaruh current ratio, inventory turnover, time interest earned dan return on equity terhadap harga saham pada perusahaan manufaktur sektor barang konsumsi yang terdaftar di BEI periode 2009-2012. Jurnal Nominal, 3(1).

Yusuf, D., Surahmat, \& Rahayu, K. F. (2016). perbandingan analisis fundamental terhadap harga saham perusahaan batubara dan perkebungan di Bursa Efek Indonesia. Jurnal Ekonomi. Universitas Pakuan.

Zulkarnaen, A. H., Syamsun, M., \& Mulana, A. (2016). Analysis of fundamental and technical factors to stock price on residential property sector companies listed in indonesia stock exchange. International Journal of Scientific and Research Publication, 6(12).

http://www.idx.co.id 